\title{
Introduction: German trade in the North Atlantic
}

\author{
MARK GARDINER AND NATASCHA MEHLER
}

\begin{abstract}
Gardiner, M., Mehler, N. 2019. Introduction: German trade in the North Atlantic. AmS-Skrifter 27, 9-24, Stavanger,
\end{abstract} ISSN 0800-0816, ISBN 978-82-7760-183-0.

Trade from 1400 onwards had an impact upon the North Atlantic region quite out of proportion to its volume. The opening of a ready market for dried fish, in particular, but also cloth, train oil and sulphur encouraged the production for export on a much larger scale than before. In return, a greater range of finished goods and raw materials was supplied by German merchants. Initially, trade was channelled through Bergen, but this system broke down, largely because English merchants sailed to Iceland. From the 1470s onwards, the number of German ships travelling to Iceland and Shetland increased. The Danish government struggled to control the trade in their North Atlantic territories, but first in the Faroes and later in Iceland, they sought to impose greater restrictions on foreign merchants. The Danes licensed ships to trade at certain ports and from 1601 attempted to restrict the trade to their own merchants. The introduction summarizes the history of German trade in the North Atlantic, and outlines its economic and cultural impacts.

Mark Gardiner, School of History and Heritage, University of Lincoln, Brayford Pool, LINCOLN, LN6 7TS, UNITED KINGDOM. E-mail: mgardiner@lincoln.ac.uk

Natascha Mehler, Deutsches Schifffahrtsmuseum, Leibniz-Institut für Maritime Geschichte, Hans-Scharoun-Platz 1, D-27568 BREMERHAVEN, GERMANY. E-mail: mehler@dsm.museum

Keywords: interdisciplinarity, North Atlantic, Hanse, trade, impact

\section{Introduction}

Of the many aspects of Hanseatic trade investigated by historians, the commerce in the North Atlantic is perhaps one of the least well understood. Certainly, there have been extensive and recent studies of the trade between the German cities and Bergen, but the activity outside this area has been much less well studied. ${ }^{1}$ The reason for this is that the trade by German merchants in the North Atlantic, excepting Bergen, has been seen by historians as a minor and, indeed, peripheral part of the main axes of European commerce in the late medieval and early modern period. It did not merit much space in Dollinger's history of the Hanse, for example, or in the Cambridge Economic History of Europe. ${ }^{2}$ If we measure the importance of trade merely in terms of its economic magnitude, then the trade from the North Atlantic, including Bergen was never on the scale of the Hanseatic trade in the Baltic. Nor was the range of commodities imported from these territories very diverse, comprising mainly dried fish, with some coarse cloth, train oil and sulphur. ${ }^{3}$ Considered in these terms the North Atlantic trade forms little more than a footnote in the history of commerce.

If, however, we shift our viewpoint and consider it from a North Atlantic position, then it seems rather different. Bergen served as a key trading post, particularly during the fourteenth century, for the networks which spread northwards to Trondheim and beyond to the Lofoten Islands, and westwards to Shetland, the Faroes and Iceland. Under Norwegian control most of the trade in the North Atlantic was channelled through Bergen which, in effect, formed a staple port for the whole of the Norse world. There was no direct contact between the merchants from Germany and England on the one hand, and their ultimate customers on the North Atlantic islands and the north of Norway on the other. Contact was mediated by Norwegian merchants (nordfarer) who controlled access to goods and also to knowledge 
Fig. 1. Places mentioned in the text (illustration: Libby Mulqueeny).
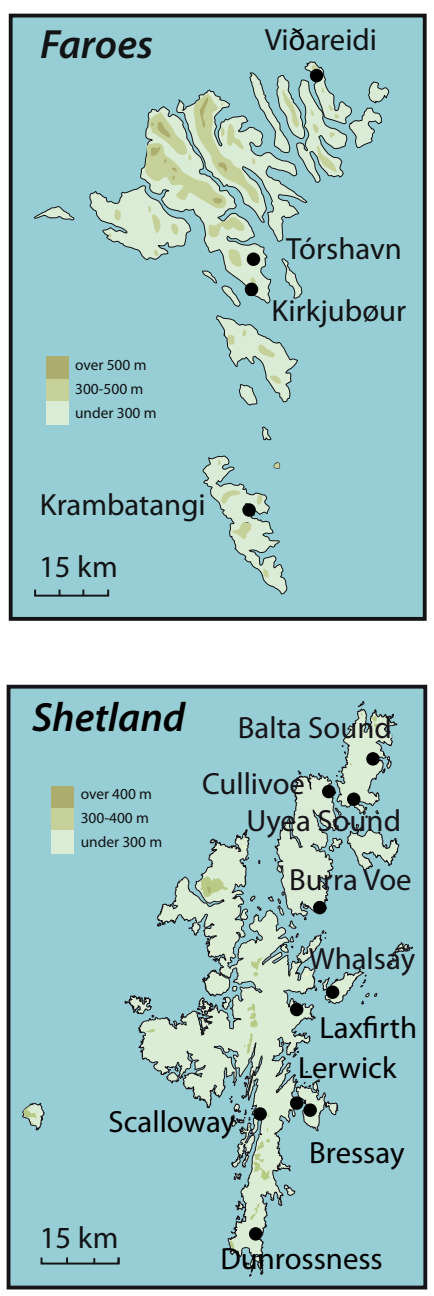
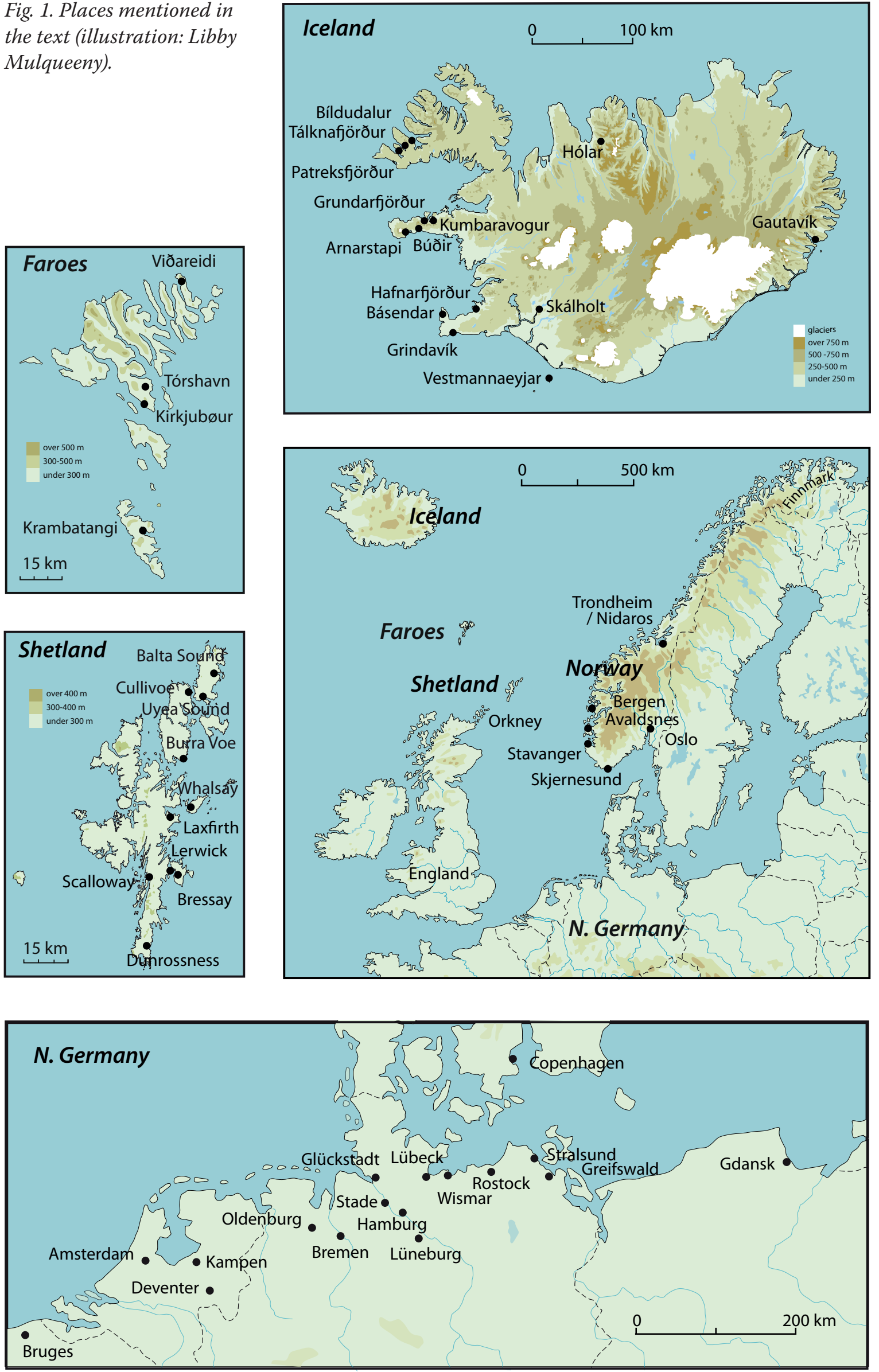
which had been picked up from foreign arrivals in Bergen. The scale of the trade may be indicated by the agreement made with Iceland in 1262 that six ships should make the journey each year; two should go to the south of the island, two to the north and one each to the West Fjords (Vestfirðir) and to the East Fjords, according to a document of $1320 .{ }^{4}$ How far this conformed to events is questionable. ${ }^{5}$ Trade with the lesser islands of Shetland and the Faroes, as well as Greenland, was almost certainly on a smaller scale. It is clear that the volume of trade expanded considerably as the system of channelling trade through Bergen broke down during the course of the fifteenth century. By the middle of the sixteenth century the number of ships travelling to Iceland from Hamburg alone was in double figures, and the size of those vessels was much larger than those in the thirteenth century. ${ }^{6}$

So, though scale of trade from Germany to the North Atlantic remained moderate in size, even at its height, the impact it had on the North Atlantic was disproportionate in political, economic and cultural effects. The trade networks, which may have initially concentrated on goods of particular interest to the elite, gradually diversified, and a wider range of manufactured and processed agricultural products was introduced to areas which had no access or, at least, very limited access to these. ${ }^{7}$ The range of commodities which had become available by the early fifteenth century is indicated in the tariff list set for exchange with the English at Vestmannaeyjar (Westman Islands) in Iceland. These included luxury items, such as wine, but also practical items, such as flour, wax, presumably for candles, salt, knives, caps and horseshoes. The items sold and recorded in the mid-sixteenth-century account book of the Bremen merchant, Clawes Monnickhusen are hardly different. They are considered in greater detail elsewhere, but they may be summarized briefly: food in the form of flour, beer and wine, items of clothing, raw materials, including iron, cloth and wood, and manufactured goods, including pots, knives and horseshoes. ${ }^{8}$ All these goods may have been available before, from merchants trading with Bergen but, with the advent of German and English merchants engaged in direct trade, the volume of goods flowing into the North Atlantic islands increased significantly. Quite as important, the consumers came in direct contact with the merchants and could indicate the sorts of wares they wished to receive from future voyages. Direct trade also enabled cultural influences to be more thoroughly spread into Norway beyond Bergen, and to the islands of Shetland, the Faroes and Iceland (Fig. 1). Trade may be regarded as 'action at a distance', in the words of an influential paper, and goods may be a Kulturträger, a 'culture carrier', but, if those goods are also accompanied by members of the culture, they are even more effective as a means of transmitting information. ${ }^{9}$

These issues form the headings which structure the papers published in this volume. The first group of studies examines the rhythms of German trade in the North Atlantic - that is the historical context in which it unfolded. The second addresses the economic impact of it in terms of the commodities which were exported to the North Atlantic and those received in return. The third part examines the cultural impact of trade on the language, society more generally and on the ships. The final section is a series of case studies which illuminate various aspects of trade in greater resolution. The primary focus of the studies in this volume is the trade between the ports of northern Germany and North Atlantic islands of Iceland, the Faroes and the Northern Isles of Scotland (Shetland and Orkney), particularly during the fifteenth and sixteenth centuries. It is hardly possible to discuss this trade without considering the port of Bergen in Norway, which had a major role in this trade. But the emphasis given to Bergen in previous historical and archaeological studies may have led to an impression that this was the only place visited by German merchants. In the papers below, we have sought to rectify this by highlighting the role of the North Atlantic islands in the system of commerce, and also other areas of coastal Norway. There are, however, some clear gaps in the coverage of the subject. Orkney is barely discussed, and the question of how far Greenland was still engaged in commercial activity by the opening of the fifteenth century is also not considered. These absences reflect the fact that there is limited evidence for trade from either place, though that should not necessarily lead to the conclusion that no commerce took place there. It is a subject which remains for future research.

One of the critical factors which recurs in many of the papers below is the question of a paucity of historical evidence. While abundant records have been kept by the German merchants, this was not equally true for their trading partners in the North Atlantic and, of course, only a portion of the records compiled have actually survived. Notably, the municipal records of Hamburg were substantially destroyed in the Great Fire of 1842 which devastated a significant portion of the old town. The written sources to allow the 
measurement of the volume of trade do not always survive, and records which might have enabled us to understand the manner in which the commerce was transacted are particularly rare. If the documents which record the German side of the trade are not always as informative as we might wish, the light they cast is infinitely greater than the records from their partners in the North Atlantic. The documents kept by civil authorities on the Atlantic territories are few in number and scant in detail about the business of trade. It is, for example, instructive to compare volumes IV and XVI of the Diplomatarium Islandicum which both contain a number of records about trade in Iceland. The former covers the period from the advent of English traders in Iceland in the early fifteenth century to the middle of the century. The latter covers a longer period, 1415-1537, and is drawn from English customs records, documents from the English exchequer, and, with the gradual ascendancy of German merchants in Iceland in the late fifteenth and sixteenth centuries, an increasing number of records from Hamburg. What is striking is that it is possible to provide a full account largely because of the English and German sources. The records from the North Atlantic islands lack detail. It is not until the seventeenth century that the court books from Shetland begin to add information about daily life in the North Atlantic. ${ }^{10}$ This disparity in perspective is an important factor to bear in mind when we consider trade which was a two-way process.

An alternative source of evidence is provided by the physical remains which still survive. Archaeology gives insights into past societies, even where there are abundant historical sources, but it has a particular role to play where there is a paucity or imbalance of evidence. Trade has traditionally been at the centre of archaeological study because the items of trade can often be confidently traced to their source using analytical methods. ${ }^{11}$ The style, decoration and fabric of pottery provide an indicator of its place of production, for example. The preoccupation with the items of trade and the trade networks which were at the centre of scholarly archaeological work in the midtwentieth century has given way to a concern, first with the way in which economic relations are embedded in society, and then with the social effects of trade. In doing so, it has sometimes lost sight of the raw facts of economics which drove that trade in the first place. In the case of the North Atlantic, the value of trade to German merchants was the difference between the cost of dried fish supplied by the producers and the price in the north German and English markets.
As the costs, including the customs dues, and the sale price began to move closer together, the German merchants found declining profit in sailing to one of the last sources of supply to which they had access, Shetland, and the trade faded away. The archaeology of trade plays a prominent part in the papers below because it provides a different and additional view of the past. For example, the discoveries underwater at Avaldsnes in Norway discussed in the papers below have driven a re-evaluation of the historical evidence and led to a new interpretation of the temporary withdrawal of the German merchants from Bergen in the period 1427-33.

\section{The history of North Atlantic trade}

The rise of German activity in the North Atlantic in the fifteenth century can only be understood from the perspective of the longer term political and economic changes which were taking place in the region. While in the twelfth and early thirteenth century the most important trading partners for the Norwegian crown had been the English, their position was increasingly eclipsed in the second half of the thirteenth century by Hanse merchants. The growth of grain exports from Baltic towns to Norway strengthened the position of German traders to such a degree that when conflict broke out in 1285-85, the Wendish towns were able to apply considerable pressure by stopping the supply of cereals. After peace was established under the Kalmar agreement, the Norwegian king was forced in 1294 to grant concessions and allow the Germans to continue to trade in Bergen and eastern Norway. ${ }^{12}$ These merchants began to dominate the trade route from Norway to England, taking commerce from both English, but particularly from Norwegian ships. The Germans created a three-legged trading route, bringing stockfish from Bergen to England, cloth from England to the Baltic towns and grain from the Baltic to Norway. ${ }^{13}$ This allowed them to dominate the North Atlantic trade. As the position of German merchants in Bergen grew throughout the fourteenth century, there was a corresponding decline in the number of Norweigan ships sailing to the East Coast ports of England. ${ }^{14}$ With the expansion of the German trade, there was a corresponding growth in the number of merchants permanently resident in Bergen. The political power of that group was, however, limited until the 1350 s by the Norwegian opposition to the creation of independent guilds. That prevented the Hanse 
merchants from organizing themselves as a separate body. But in 1366 the Hanse Diet (the assembly of the Hanse confederation) agreed to the regulations drawn up by the German merchants controlling this 'colony'. This Bergen Kontor not only regulated and managed the trade of the Hanse merchants in the city, but also allowed them to act as a unified body in dealing with the Norwegian crown. ${ }^{15}$ Their English rivals, by contrast, were ill co-ordinated, and merchants from rival ports could rarely agree on a common course of action. Their only means of exerting their position was through the English king, if indeed they could persuade him to act on their behalf. ${ }^{16}$ The failure of the English to establish a firm base in Bergen was a reflection of the weaker municipal government at home and the absence of any overall body to represent the commercial interests.

The foundation of the Bergen Kontor was followed within a couple of years by the outbreak of war between the Hanse and Norway, part of the wider struggle to establish control around Øresund. The German merchants withdrew from Bergen, allowing their English counterparts briefly to reassert their position. When the merchants returned to Bergen in 1372, they drove out the English. The position of the Germans and those elsewhere within the territories of Zealand, Guelders and Holland was consolidated by the grant of a charter of 1376 allowing them to trade freely in Norway. ${ }^{17}$ Even so, the situation of the English in Bergen gradually improved in the 1390s, though the commercial rivalries increasingly led to confrontations, especially as the Norwegian waters were fished by the English. The most notorious of these incidents was the attack on a hundred fishermen at Wynforde, identified variously as Kvinesfjord or Vindefjord, and discussed below by Stylegar, Nymoen and Eikli. ${ }^{18}$

All these events must be seen within the overall context of the rising demand and hence the growing profit in the fish trade. Nedkvitne has shown that the price of fish rose in the wake of the Black Death as changing living standards increased the demand for protein-rich foods. The significance of the North Atlantic emerged in the later fourteenth century as it became a major source from which fish could be obtained, whether by catching it or by purchase from local fishermen. The enhanced profits of the merchants allowed greater investment in larger ships to voyage to more distant sources. ${ }^{19}$ While for the Germans, this allowed the consolidation of an already existing trading system based on stockfish supplied by Norwegians to Bergen, for the English struggling to hold their position in Bergen, it involved finding new sources of fish. In this lay the central difference between the German and English approaches. The German merchants were dealing with preserved fish caught by others; the English pursued a dual strategy of both trading and fishing. Trading was largely done by merchants from the larger English towns, while fishing was often undertaken by vessels from smaller ports. Many vessels, however, engaged in both activities, diversifying the risk. ${ }^{20}$

The continuing primacy of Bergen as the staple port for the North Atlantic might have been assured were it not for a number of factors. ${ }^{21}$ The first was the commercial rivalry between the German and English merchants to obtain access to the fish resources of the North Atlantic. The English merchants found themselves, either less successful in commerce, or entirely excluded from the market, and turned to fishing themselves as an alternative means of obtaining a supply. The incident at Wynforde involved ships from Cromer and Blakeney, two small ports in Norfolk which were primarily involved with fishing and with trade as a secondary matter. Similarly, the fishermen of Cromer and nearby Blakeney had petitioned the king in 1383 to avoid having their ships commandeered for transporting horses and asked for them to be released to fish on the coasts of Denmark and Norway. ${ }^{22}$ The growth in demand for fish coincided with the fading of the herring fishing industry on the east coast of England. The causes of this are unclear, but if herring was either unprofitable or unobtainable, cod and whiting provided an alternative catch. ${ }^{23}$ This was the context for the first voyages made to Iceland by English ships. The date of these is uncertain, although they are first mentioned in the Nýi Annáll under the year 1412 . However, a reference to a murder by 'foreign merchants' on the Vestmannaeyjar in 1397 suggests that there were earlier voyages, of which few details have survived. In the papers below, Rolf HammelKiesow notes that the Hanse Diet in 1416 seems to have omitted any prohibition on sailing to Iceland for trade; it has been suggested that by 1429 ships from Lübeck, Gdansk and Hamburg were trading there, and certainly ten years later a Dutch ship was returning from Iceland with a cargo of stockfish when it was plundered. ${ }^{24}$ The developing trade by English, Dutch and perhaps German merchants led to a prohibition issued by King Erik in 1425 against the merchants going to northern Norway, Iceland and the other North Atlantic tributary territories. ${ }^{25}$ How far this was observed is questionable. Certainly, the 
Bergen merchant with a German name, Henrik Soost (evidently from Soest in North Rhine-Westphalia), held land on Shetland in 1452, which may well have been connected with trade from those islands. ${ }^{26}$

The attitude of the English to observing the rules of trade was ambiguous as that of the Hanse Diet. In 1415 King Henry V directed ships in the east coast ports from Berwick to Harwich to cease going to the islands of the kings of Denmark and Norway and particularly Iceland' for fish, but that only applied for one year. ${ }^{27}$ However, the temporary injunction was followed in 1429 by a permanent proclamation which was aimed especially at ships going to Finnmark in northern Norway, but also elsewhere, and instructing them to go only to Bergen to trade. There, they had been granted the same rights as German merchants. ${ }^{28}$ The same injunction was repeated in 1434 with Hålogaland in northern Norway mentioned in addition. ${ }^{29}$ If this was initially enforced enthusiastically with the seizure of goods, it soon began to be relaxed with the English king selling licences to make the voyage to Iceland and Finnmark. ${ }^{30}$ It is not clear whether the reference to the two destinations was a standard wording adopted by the Chancery clerks, or if this reflected the pattern of voyages made my English ships. ${ }^{31}$ Licences were also issued to the bishops of Hólar and Skálholt to engage in trade with English ports. ${ }^{32}$ The trade was regularized by an agreement of 1465 when the Danish king allowed the English to sail under licence to Iceland, while continuing to ban sailings to Finnmark and Hålogaland to ensure that Bergen maintained its central place for the Norwegian stockfish trade..$^{33}$ The now-legalized operation of trade was up-ended in 1467 when the governor of Iceland, Björn Thorleifsson was murdered by English sailors at Rif in Snæfellsnes as he tried to prevent them from trading without paying customs. The response of the Danish king, who had few resources in Iceland to exert his authority, was in June the following year to seize English vessels in Øresund. ${ }^{34}$ The involvement of ships from Gdansk in the seizure contributed to a counter-move by the English King Edward IV against Hanseatic ships and merchants, which sparked a conflict with the cities of the Hanse. In the same year the Danish King, Christian I granted the Hamburg merchants a licence to sail direct to Iceland. ${ }^{35}$

It is difficult to ascertain how many German merchants made direct voyages to Iceland before 1468, but the interests of those who sought direct trade with the island gradually began to gain ground over those who wished all trade to be directed through Bergen. ${ }^{36}$
The right to engage in trade directly with Iceland was not, however, followed immediately by a surge of activity. Not apparently until 1475 did two ships from Hamburg first sail there directly. The following year a third Hamburg ship returning from Iceland ran aground on the east coast of England, and in 1479 a Bremen captain was shipwrecked off Shetland while on his way to trade in Iceland. ${ }^{37} \mathrm{~A}$ rather interesting insight into the situation in Iceland is given in an account of 1473 when it was recalled that two ships, one from Veere in Zeeland and the other from Amsterdam in Holland had fought in 1471 with four ships from England in the Icelandic port of Hafnarfjörður, suggesting that the Hollanders' ships were also engaged in direct trade. Two of the four English ships at Hafnarförður were captured, one of which had previously been seized by the English from the Germans, the other, the Peter of Hull. ${ }^{38}$ Conversely, a ship from Hamburg was attacked in 1486 near Hafnarfjörður by an English vessel; it was captured and taken to Galway in Ireland where it was sold. $^{39}$

The complaints of the Bergen merchants to the Hanse Diet in 1482 about the Islandfahrer from Hamburg, Danzig and Bremen sailing directly to the island had little effect. ${ }^{40}$ Equally, the attempt of the previous year by the Norwegian Council of the Realm to prohibit trade was also unsuccessful. ${ }^{41}$ The confused bans and partial bans on trade enacted by both the Danish king and the Hanse Diet are considered in greater detail in the paper by Hammel-Kiesow below. It is clear from his account that the interest in trading directly with Iceland was considerable, the means to prevent it were slight and any rules which might be created could be circumvented. In that situation, the prohibition on trade with the North Atlantic islands effectively began to fade away. Events on the ground must also have been spurring German merchants to take part in direct trade. An agreement between Denmark and England made in 1490 concluded the hostilities between the two nations which had followed from the murder in 1467 of the Danish governor in Iceland. It allowed the English to sail to Iceland legally, if they obtained a licence which lasted seven years and paid a rather minimal fee of $6 s .8 d$. for each voyage. ${ }^{42}$ The situation was also regularized in Iceland where the laws named after the governor, Didrick Pining established the equal rights of English and German traders. ${ }^{43}$ While the ban on sailing to Iceland persisted in English law until 1510, and indeed licences continued to be issued by the English king up until that time, the reality was that there were few limitations on such 
voyages. ${ }^{44}$ Meanwhile, the Germans were becoming increasing well established in Iceland and provided clear competition for the English merchants.

The two decades from 1510 onwards saw a growing number of conflicts in the waters of the North Atlantic, and in Iceland more specifically. On 1511 the James of Hull attacked a ship from Hamburg and took the goods and the captain back to its home port in England, and in the same year another Hamburg ship bound for Iceland was captured. There was a further assault on a German ship in 1514 when the captain was carried off to Newcastle. ${ }^{45}$ The disturbances in Iceland were amongst the issues raised by the envoys sent by the Danish king, Christian II to the English king, Henry VIII in $1515 .{ }^{46}$ However, the conflict between the Germans and the English were not the only problems faced by ships in the North Atlantic. The Iceland-bound English ships were cautious of sailing north and in 1513 sought to avoid the notorious Scots pirate, Robert Barton. ${ }^{47}$ Equally, there were conflicts between merchants from north Germany. Hans Tappe who had established a trading base in Grundarfjörður assaulted other German merchants who attempted to operate from that place. ${ }^{48}$

Beyond the commercial rivalries, the merchants, and indeed the inhabitants of the North Atlantic islands, had a common interest in successful trade. The agreement made between the merchants of Hamburg and Bremen, and of England and the regional assembly in the southern quarter of Iceland in 1527 reflected a desire to be able to work together. The Icelanders agreed to provide clean dried fish and the merchants agreed that they would use accepted measures, stay only during the summer months and not overwinter. The latter was a consistent rule which the Norwegian and later Danish rulers had insisted upon. Unsold goods might be left in the country for sale over the winter by an Icelandic associate, but only at the price established during the summer months. ${ }^{49}$ It was an agreement made just before the trading situation began to deteriorate further.

Competition for dried fish and space in harbours was particularly fierce in the south-west of Iceland, the best fishing grounds. The situation had reached a poor state when Frederick I of Denmark wrote to Henry VIII of England in c. 1530 about the disputes between ships from Hamburg and those from England on the coast of Iceland. ${ }^{50}$ The officials in Iceland saw the German merchants as allies in their attempts to regulate the English traders. In April 1532 a ship from Hamburg captained by Luke Schmidt fought with the assistance of Icelanders against two English vessels in the harbour at Básendar on Reykjanes with the result that one of the latter was stranded and the other surrendered. Later that year, the dispute reached a head when the English, according to various reports, either stole fish purchased by German merchants or refused to pay their custom dues. The English sailors, led by John Breye, sensing trouble ahead, built a fortification, a particularly contentious act and something with which they had been charged in previous decades. The Germans were led by the bailiff of Iceland, Didrik van Minden, who perhaps not coincidentally came from Hamburg. They entered the fortification at Grindavík and killed Breye and his companions. It is alleged, perhaps with some exaggeration, that forty Englishmen were killed in Iceland that summer. ${ }^{51}$

The consequences of these events continued for a number of years. A vessel from Hamburg in 1543 drove an English ship out of a harbour in Iceland. ${ }^{52}$ Yet, on the whole, the situation resolved itself so that the Germans concentrated on trading with the Icelanders for dried fish, while the English largely devoted their activity to fishing, though merchants from both areas continued to trade in Vestmannaeyjar. Meanwhile, external events were making changes which affected the North Atlantic. The death of the Danish king, Frederick I in 1533 launched a struggle for succession which embroiled the Norwegian Council of State on behalf of one candidate, Christian II. The victory of his rival, Christian III, led to the abolition of the Council of State, consolidating power in the hands of the Danish crown. The policy pursued by the king from that point was to seek to advance the interests of the Danes in the North Atlantic against the commercial interests of the Germans, English or Dutch. In 1544 the governor, Otto Stigsen confiscated fishing boats which Hamburg merchants had supplied to Icelanders to fish. ${ }^{53}$ Following the protests by the German merchants, it was agreed the following year that foreign boats were not to be permitted, although ships might carry boats to be used to ferry goods to the shore, a concession granted in return for higher customs. ${ }^{54}$ The next stage in the tightening control by the Danes was the lease of the whole trade of Iceland in 1547 for a period of ten years to the city of Copenhagen. ${ }^{55}$ However, the Danish merchants lacked the ships to carry out the scale of trade required, nor the effective powers to enforce this monopoly in Iceland.

The initial failure of the Danish crown to wrestle control from the German merchants did not mean that all such efforts were abandoned. Instead, restrictions 
were placed, primarily on sulphur, but also on other commodities. ${ }^{56}$ Even greater control on German trade was exercised from 1562, requiring merchants to obtain licences for specific ports. In some ways this was an extension of the long-standing Norwegian policy of directing ships to specific ports in order that the benefits of trade should be widely distributed. The aim now seems to have been as much to control the activities of merchants as to help the Icelanders. ${ }^{57}$ Equally, the Danish king sought to limit the activities of the English which had shifted overwhelmingly from trading to fishing. It was hardly possible to enrol the German merchants to assist in this, since they were themselves so restricted. Instead, in the 1560s Scottish vessels were encouraged to attack against the English. ${ }^{58}$ The Hamburg merchants meanwhile were gradually being displaced from ports in which they had long operated and the licences to trade granted to Danes. The harbours of Rif and Arnarstapi in Snæfellsnes were given to Anders Jude, a merchant from Copenhagen and Gert Bonhofer was awarded the ports of Patreksfjörður, Bíldudalur and Tálknafjörður in Vestfirðir (the West Fjords) in $1565 .{ }^{59}$ Yet, the policy was hardly successful, and in 1579 the rights were restored to Hamburg to trade with fifteen ports in Iceland. ${ }^{60}$ As a result, more ships arrived in that city from Iceland in the 1580 s and 1590 s than ever before, leading to a rivalry to get licences and seek harbours. ${ }^{61}$ These restrictions on foreign vessels were not, as is sometimes alleged, to protect the Icelanders from the abuse of foreign merchants. On the contrary, Icelanders wrote to the Danish king in 1592 to ask that merchants should be allowed to sail to any harbour they wished. ${ }^{62}$ There was also an upsurge in illicit trade between Icelanders and English vessels. The English were ostensibly going to Iceland just to fish, but undertook trade as well. In 1593 more than 55 ships travelled from England to Iceland. ${ }^{63}$

This was, however, the Indian Summer of the Icelandic commerce because, in 1601 the Danish king wrote to Hamburg and Bremen to advise them that future trade was to be restricted to his own citizens. Many of the licences for Iceland expired in 1602 and from then on merchants were only permitted to go to collect the outstanding debts owed by the Icelanders. ${ }^{64}$ In reality, ships continued to sail from Hamburg because, yet again, the Danish merchants lacked the vessels for the level of trade required. Hamburg was also pivotal to the Iceland trade because it was the centre for selling stockfish for continental Europe. Finally, by the 1620 s the era of German traders in
Iceland was over and the Danish monopoly properly established. ${ }^{65}$

The discussion so far has examined the situation in Iceland, which by the opening of the sixteenth century had emerged as the most important place of trade for German merchants in the North Atlantic, excepting only Bergen. It is useful now to consider the situation more widely. The aim of the Norwegian and later Danish kings was to maintain control over the operation of trade, as far as possible, to prevent merchants having excessive power and influence in areas which were at the peripheries of their dominions. To do this, they sought to determine the ports at which the traders could operate. They fixed the prices of the goods and ensured that goods sold in the winter, when there was limited supply, were at the same price as those in the summer. Generally, however, they required all merchants to leave before the onset of winter so that they did not become permanent residents. The somewhat exceptional establishment of wintersitzer (winter residents) in Bergen was preceded by an extended period of inconsistent policy by the Norwegian kings who alternately allowed it and then forbade it. ${ }^{66} \mathrm{~A}$ further aim upheld by both the Danish and Icelandic authorities was to prevent foreigners from employing Icelanders. The intention was to reinforce the long-standing intention to ensure that all workers were connected with a farmstead, the basis of Icelandic society. ${ }^{67}$

These aims were reflected not only in the operation of trade in Iceland, but in part, at least, across the North Atlantic islands. For example, the deployment of merchants to different ports is evident in Shetland and even though the islands had passed out of the control of the Norwegian-Danish crown in 1469. In a letter written to the mayor and council of Bremen in 1563, Ola Sinclair, the chamberlain of Shetland explained that the harbours of Scalloway, Laxfirth, Bressay, Whalsay, Dunrossness, 'St Magnus island', Vaila Sound and Papa Sound were the main harbours, but there were others on the islands to the north at Burra Voe and Cullivoe on Yell, and Uyea Sound on Unst. He continued, detailing why he had refused a Bremen ship permission to trade at Balta Sound. ${ }^{68}$ Once merchants had established themselves in one or other of these ports, they often bought land for their booths or trading shops and expected to return to them over a number of years. Price-fixing was also a well-established custom in Shetland where it was undertaken by the foud (governor) ${ }^{69}$ The practice of 
restricting the number of ports can be found even as late as 1670 when it was agreed to close the port at Gloup and restrict trading on the island of Yell to Cullivoe. ${ }^{70}$ Winter residency was never forbidden in Shetland, but because the main period of both fishing and trade was in the summer months, there was little reason to stay there after that season.

The early history of trade in the Faroe Islands is less well documented than Iceland. In 1262, at the time it was agreed that six ships should go to Iceland from Norway, it was also determined that two ships should depart annually from Bergen for the Faroes. ${ }^{71}$ Whether that level of trade was ever reached is questionable. Trade by German merchants was established and lasted until 1524 when the Danish bailiff at Bergen, Jørgen Hanssøn was granted a monopoly on exports from the Faroes. A few years later, in 1529, the right to operate the monopoly was granted in turn to Thomas Koppen, a Hamburg merchant. ${ }^{72}$ The monopoly continued intermittently under successive Hamburg merchants until 1591 when it was brought under the control of Danish traders. ${ }^{73}$ Here too, a price-fixing regime operated to ensure that the foreign merchants did not sell at inflated values. The scale of investment, perhaps by the Hamburg merchants, is evident from the stone-built, lime-mortared building of Munkastovan in Tórshavn. This is discussed below by Arge who stresses how unusual such a building was in the context of the Faroe Islands.

The outline above has established that the German trade with Norway and the North Atlantic islands can be broadly divided into three phases. The first is marked by the gradual increase in trade during the later thirteenth century and the corresponding strengthening of the role of Bergen as the centre of the network and the place at which tax could be levied. That second phase continued until during the course of the fifteenth century the central function of Bergen began to fade, largely though the competition for access to the products from the region from merchants of different countries. The English, partially excluded from Bergen and operating a less organized system of commerce, began to trade directly with Iceland. The Dutch too began to sail directly there. The third phase is marked by the subjugation of the interests of the Norwegians and later the Icelanders to those of the Danes, which occurred from the mid-sixteenth century onwards. The full effects of this took some time to be worked through until the Danish merchant fleet was of sufficient size to take over the trading activities of the Hamburg merchants, in particular.
One way of looking at the history of North Atlantic trade is to view it successively as the eclipse of Norwegian power, of Hanseatic dominance, and the ultimate replacement of both by the mercantilist policies of the Danes. To do so, begs many questions, not least about whether the Danish activities were truly mercantilist, and if that term is indeed a useful concept. ${ }^{74}$ Another way of looking at the situation is to regard the Danish approach to the North Atlantic territories as merely a continuation of the Norwegian one, treating them as skattlands, tribute-paying lands whose interests were to be subjugated to those of the dominant power. ${ }^{75}$ English and German trading activity in the early fifteenth to late sixteenth century should then be regarded as an interlude in the longer period of Scandinavian dominance. Such an argument is reinforced by the continuities of trading practice which included the regulation of prices and the fixing of harbour sites. Different scales of chronological resolution allow varying perspectives on the trade in the North Atlantic.

\section{Economic impact of trade}

Trade in the North Atlantic, like much trade elsewhere in medieval and early modern Europe, operated on the extension of credit. Credit was granted not only to the larger suppliers, but also to the large numbers of small producers. Yet, the growing demand for credit, even on the comparatively small scale required for merchants operating in the North Atlantic, came just at the point when it was becoming increasingly hard to obtain. The supply of credit was closely tied to the circulation of bullion, because without the latter there was little possibility of an eventual repayment of a debt. From the later fourteenth and into the fifteenth centuries, bullion flowed out of western Europe to the Mediterranean and into the Arab world, so that by the late 1430s and early 1440s the supply of bullion had withered away almost entirely. It was not until the late 1460s that new supplies of silver began to arrive, bringing quantities of coins back into circulation. ${ }^{76}$

Coins themselves played little part in the economy of the North Atlantic and in some regions virtually no coins were in circulation, even when bullion was abundant. Credit and barter were the two mechanisms which enabled exchange to take place in this region. Credit was used from a very early date. The Jónsbók (1281) lays down rules concerning the redemption of debts in Iceland and in 1294 further measures were introduced to help merchants obtain the payments 
owed to them..$^{77}$ These debts must have been to the Norwegian merchants who were the main ones trading with Iceland at this period, but from the midfourteenth century, as the price of stockfish rose, credit also became common in the trade between Norwegian fishermen and Hanse merchants. The advantage to the overseas merchants was that it bound the producers to them and ensured that they would provide commodities when they returned in subsequent years. The German merchants agreed amongst themselves that indebted Norwegians could trade only with those to whom they owed goods, and not others. So, they were particularly annoyed when, in 1372, Norwegians with credit owing, traded not with German merchants, but instead with the English. ${ }^{78}$ The English, no less than the Germans, were keen to use the credit system to maintain supplies of fish, not only with the Norwegians but also with the Icelanders, when they started voyaging there. Licences to sail to Iceland were granted in 1439 and 1451 by the English king to Bristol merchants on the possibly specious grounds that they needed to go there on account of the debts which were owed. ${ }^{79}$

The credit system tied both merchants and fishermen into a cycle of repeated annual visits to the same places. The results are particularly well documented in Shetland where, perhaps unusually, there were debts of merchants to suppliers, as well as debt owed by suppliers to merchants. ${ }^{80}$ The merchants established close relations with the local communities, as discussed further below. The inscription on a graveslab in Lunda Wick church records that Segebad Detken had been coming to Shetland for fifty-two years. ${ }^{81}$ Much the same sort of feeling may have existed between the Hamburg merchants and the communities on the Faroes, as the gift of a crucifix to the church of Viðareiði, discussed by Simun Arge here, seems to suggest. Yet, for all the affection which the people of the North Atlantic may have felt for their merchants, the relationship was, in the last resort, an economic one. The system of credit worked to the benefit of both parties, guaranteeing a market to the producers and a supply to the purchasers.

The most informative insight into the workings of the credit system comes from Bremen merchant's debt register for trade at Kumbaravogur in Iceland discussed below by Adolf Hofmeister, which uniquely allows the 'market reach' of the trading site to be mapped. ${ }^{82}$ A somewhat more difficult-to-interpret source is the account drawn up by Otto Mack in 1653 recording the fish delivered to him and the goods provided from a trading site, evidently on the east side of Mainland in Shetland. ${ }^{83}$ Almost a century earlier a German merchant had complained that the sites to which they had been directed to sail on Shetland already had merchants there who were owed debts, and therefore that merchant, who had not previously visited the ports could not hope to obtain fish there..$^{84}$ Merchants operating from Bergen practised a similar system, though they had no direct contact with fishermen, since the fish was brought south to the port by a nordfarer who acted as an intermediary. Nevertheless, the Bergen merchants kept records of the individuals owing them money in Iceland, Shetland and the Faroes. ${ }^{85}$

Social relations and economic relations were not two separate matters, but were closely connected. As Munro has commented about Europe more generally,

'With inadequate or too costly legal measures to enforce debt repayment, credit transactions depended upon a personal trust that could be generated only by close relationships between relatively few merchants. ${ }^{186}$

One of the difficulties increasingly faced by merchants in the later sixteenth century in Iceland was that the systems of trust and credit were not well suited to the short-term licences for trade offered for specific harbours by the Danish crown. A partial solution was the transfer of debts from one merchant to another, something Hofmeister mentions in his paper below. New merchants inherited the debts, and hence the payments of fish, from their predecessors.

The effect of a system based on the advance of credit and of barter was to prevent the easy accumulation of capital in the North Atlantic territories. There was no simple means by which capital could be gathered and stored, except through the accumulation of debts owed by others, an option available only to those with existing wealth. The result was that in Iceland the power of the church was consolidated. As demand for fish by foreign traders increased, the farms on the coast and outlying fishing stations used by more distant farms were bought up by the church to gain control over fishing operations. As a consequence, every farm in Grindavík, a key centre of fishing in south-west Iceland, fell into the hands of the bishopric of Skálholt during the fifteenth century. ${ }^{87}$ In Shetland, an archipelago with an extensive coastline, the situation was rather different. The sites for fishing bases were almost ubiquitous and the church did not seek to monopolize the activity. Instead, the growth of the power of Scottish landlords over fishing lay in the eighteenth century by which time German merchants played a lesser role in trade.$^{88}$ No 
fishing industry emerged which was separate from the structures of farming in Iceland and Shetland. Instead, fishing remained an adjunct to the activity of farming. In Iceland the Germans did seek to encourage the development of a distinct industry by supplying boats to Icelanders, but the Danish crown in 1544 sought to forbid it to maintain the primacy of the farmer in society. ${ }^{89}$

The aim for the producers in the North Atlantic was, of course, not to accumulate capital, but to obtain goods which were otherwise unavailable. These included clothing, food, goods including fishing line and, in Shetland in the seventeenth century, guns, tobacco and spirits. It is important to emphasise that these goods served not only as markers of wealth, but had a social significance indicating an acquaintance with a wider world beyond. The finds of pottery discussed below by Demuth outside the urban areas may not be evidence of direct involvement in trade, but rather of access by various routes to the goods which had been brought to the North Atlantic by Hanseatic merchants. $^{90}$ This also implies a cultural influence which must now be examined.

\section{The cultural impact of trade}

The trading contacts between the German merchants and their clients - farmers, clergymen and officials - in Iceland, Shetland and the Faroes during the fifteenth and sixteenth centuries had a profound impact on the culture of the islands. The cultural influences from northern Germany were transmitted both through personal interaction and through the medium of material culture, which included foodstuffs and also artefacts. Amongst the direct personal contacts, we should include German traders and sailors who stayed on the islands for the summer and did not only dwell in their trading posts, but also travelled through the islands and engaged with vendors. Although overwintering was prohibited in Iceland, exceptions were made for young boys (liggers) who were allowed to remain with local farmers, learning Icelandic. ${ }^{91}$ Occasionally, German barbers were hired to move to Iceland. ${ }^{92}$ The evidence suggests that personal contacts between the Germans and the communities they traded was particularly strong in Shetland. Smith in his paper below notes how the congregation of the church of Lunda Wick in Unst in Shetland wrote a testimonial in 1661 for two German merchants, Herman and Gert Detken, saying that they had acted honestly and fairly in their trading. Their predecessor, Segebad Detken had been buried in the same church in 1573, having traded in Shetland for fifty-two years, according to the inscription on his tombstone. ${ }^{93}$ The close connections implied by these suggests that merchants might build close, long-term relationships with the local community, and it is hardly possible to imagine that their contacts were limited to discussions connected only with commerce. Inevitably, the merchants, as well as the crew of the ships, who stayed for many months during the summer exchanged news and other information. The traders provided not only a source of goods, but also information about the world beyond.

Trade opened the North Atlantic territories to wider influences coming from continental Europe and England, and this was particularly true for the religious connections. The bishops of the two Icelandic sees of Skálholt and Hólar, and, in the Faroes, of Kirkjubøur, were appointments made by the archbishop in Trondheim. Up to 1340 it was common, however, for the Icelandic bishops to name their successors, which were then confirmed by the archbishop. After 1340 the nominations originated in Trondheim and, unsurprisingly, the clerics granted the episcopates were Norwegian, rather than local men. During that period the appointments for the bishops of Skálholt were commonly drawn from monks in monasteries around Bergen, a link which reflects the trading connections. From 1380 the appointments were made by the papacy and the nominees were increasingly international in origin and reflected the nature of trading contacts. These included at Skálholt in 1435 John Williamson Craxton (an Englishman), in 1437 Gozewijn Comhaer (a Dutchman) ${ }^{94}$ and in 1448 Marcellus de Niveriis (a German), and for the bishopric at Hólar, three Englishmen: John Williamson Craxton in 1425 (later translated to Skálholt), John Bloxwich in 1435 and Robert Woodburn in $1441 . .^{95}$ In the Faroes too, foreign bishops are found in the period after 1380, including the appointment in 1385 of William Northbrigg, in c. 1391 Vigbald (apparently German) and in 1408 Jon I, the German. ${ }^{96}$ Orkney and Shetland were served by Andrew Pictoris (Andreas Alamani), a German, who was bishop of Orkney from 1477 to 1505. His illegitimate son, Henry Phankouth, educated in Cologne, was archdeacon of Shetland (1501-29). ${ }^{97}$ Nor was it only to the church that foreigners were appointed. A German, Didrick Pining in 1478 served as governor in Iceland, a post also held by his nephew from $1490 .^{98}$

The merchants also brought with them knowledge and new ideas from abroad, and everyday items, but 
also ecclesiastic objects and fine arts, such as the altarpiece of Hólar cathedral, made in northern Germany. ${ }^{99}$ New ideas and knowledge were spread through the first printing press that bishop Jón Arason ordered in Hamburg to be shipped to his episcopal see at Hólar around $1530 .{ }^{100}$ Most dramatically of all, the spread of the Reformation from Germany to Iceland was very much a result of the trading connections between both parties. ${ }^{101}$ In 1533, Hamburg merchants built a Lutheran church in Hafnarfjörður, the first such church in Iceland. ${ }^{102}$ The merchants obviously felt the need for Lutheran spiritual guidance on an island deeply rooted in Catholic traditions.

The Icelandic historian, Björn Porsteinsson argued in 1972 that the contacts between the Icelanders and the Germans had a profound impact on the Icelandic society. ${ }^{103}$ Subsequent research has emphasised the many ways in which northern German culture penetrated the Icelandic society, to the extent that it is claimed that Iceland became, in effect, a cultural colony. ${ }^{104}$ In stating this, much depends upon how colonialism is defined. Historians tend to focus more on political decisions and establishment acts, economic power and inequality; anthropologists emphasise sociological and cultural changes brought upon through contact. It is the latter approach which is considered here. Alessia Bauer below presents a linguistic perspective and shows how Middle Low German, the language of the merchants, was picked up in late medieval Icelandic. The impact of German on Norwegian has also often been discussed, and here Inge Særheim looks at the impact on Scandinavian languages more generally, and on personal and place-names. Yet, it should be emphasised that the influence did not move only one way, though the impact of the inhabitants of the North Atlantic territories on Hamburg and Bremen has yet to be thoroughly explored. Some Icelanders moved to those German cities, to stay there until the end of their lives, and others settled in England. ${ }^{105}$ The response to the meeting of cultures was not always positive. The German merchant, Gories Peerse was not complimentary about the Icelanders, describing them as uncivilized people. ${ }^{106}$ Equally, the English author, Andrew Borde wrote in 1542 that they were 'beastly creatures, unmannered and untaught' and imagined that they lived in 'caves', though that term was used for the turf-covered houses in Iceland. He was only a little less condemnatory about the Shetlanders whom he considered content with coarse clothing. ${ }^{107}$ Such prejudicial views were not universal in England, and when Roger Braunche, a merchant of Lavenham in Suffolk, wrote his will in 1490, he left a bequest to his 'Iceland servant'. ${ }^{108}$

Cultural contact between the North Atlantic and Germany operated at the personal, religious, intellectual and linguistic levels, but the economic force underlying it was the movement of goods. A further element of cultural exchange was through the medium of objects, a concept which is conveyed by the German word, Kulturträger. In discussing this, Mehler has distinguished four classes of material culture, but here these can be reduced quite simply to two types - finished goods and raw materials. ${ }^{109}$ Although in using the term 'material culture', we often have in mind only artefacts, we also need to include food and drink, including flour, alcohol and tobacco, which were important elements in cultural exchange. The consumption of these was built into the very business of establishing a rate for the exchange of goods at the beginning of commerce: in late sixteenth-century Shetland, the process of price-setting was accompanied by the consumption of a barrel of beer. ${ }^{110}$ Clothing was equally significant as a cultural marker and Hayeur Smith below discusses the import to Iceland of clothing made in England and continental Europe, which was evidently deemed so desirable that Icelandic laws warned against the use of these. She argues that the use of imported clothing may not merely have been a statement of wealth and fashion, but also of religion. ${ }^{111}$ The impact of imported clothing in Shetland was also remarked upon by John Brand, noting, that 'the gentry want [lack] not their fine stuffs, such as Holland, Hamburgh, etc. do afford, so that they are to be seen in as good an order and dress as with us in the south.'112

Oversea trade also left a cultural mark in the form of ships. Archaeological evidence for ships in the North Atlantic in the period 1400 to 1700 is very scarce. So, we have to turn to ship finds of that period from northern Germany and the Baltic instead. Ship archaeology has for a long time been under the shadow of ship history, but in recent years has started to free itself from that dominance. Very often, the friction between information on ships deriving from written sources and that from archaeological sources becomes evident in the ship material discovered, as Belasus and Zwick explore in their chapters. Furthermore, the archaeological record reveals that several ship-building methods coexisted at the same time and that it is difficult to disentangle the ways and directions of how cultural and technological influence flowed. The way in which economic impact 
is emeshed with cultural impact is stressed by Belasus who draws attention to the economic pressure that led to improvements in ship building techniques, for example with the technological improvement of vessels to make them ocean-going and fit to cross the North Atlantic.

\section{Studies of particular places}

The final section of the present volume looks at specific places, beginning with three studies of the harbour at Avaldsnes, near Haugesund in western Norway, a point on the Norðvegr, the sailing route up the coast of Norway. ${ }^{113}$ Most of the papers published here arose from a conference held at that place on the subject of 'German traders in the North Atlantic' in May 2013. It is appropriate that the question of the nature of this site, a temporary base established by Germans who had left Bergen, should be thoroughly examined in the papers here. Since that time, the excavations by Dagfinn Skre have been published, recording the traces of a stone-built secular building which has few parallels in Norway and probably marks one part of the royal manor. ${ }^{114} \mathrm{~A}$ further tangible link connecting Avaldsnes and merchants is provided by the house marks or merchants' marks scratched into the soapstone jambs and quoins of the church at Avaldsnes and into the timber of the door. ${ }^{115}$ Gautavík in south-east Iceland, another place studied here in detail, is one of the few other localities in the North Atlantic, apart from Bergen where a trading place has been excavated in detail. That work took place more than forty years ago when Gautavík was not connected with German trading activities. A re-examination of the evidence is presented here, interpreting Gautavík as a sixteenth-century German trading site.

\section{Conclusion}

This book brings together latest research on the Hanse in the North Atlantic drawing on a variety of disciplines: history, archaeology, zooarchaeology, dendroprovenancing and archaeoentomology. The concluding paper by Stuart Jenks, an historian of Hanse history, is printed here largely as it was given at the end of the Avaldsnes conference, emphasising the difficulties inherent in interdisciplinary work. It is appropriate to finish the volume with a reflection on the problems that still lie ahead in producing an integrated understanding of this particular episode of European trade. As Jenks emphasises, the problems of incorporating different strands of knowledge should not be wished away, but confronted, and may in the end prove to be impossible to overcome. While we can argue that the papers here represent a multi-facetted view of German trade and provide a more thorough view than one approach alone could offer, there are also difficulties of comprehension, not merely of terminology, but also of significance. These difficulties are accentuated because of the international character of the contributors to this volume who have approached it from their different national traditions of scholarship. As this introduction began by arguing, the significance of this branch of trade depended upon whether you stood on the harbour side at Hamburg in Germany or the shore of Hafnarfjörour in Iceland. In the former place, it may not have been so significant, but in the latter, it assumed a much greater importance. We should be clear that the purpose of, neither the conference which gave birth to this volume, nor of the present book, was to produce a unified perspective. Rather, it is hoped that by providing a variety of views on aspects of the German trade in the North Atlantic, we have cast considerable new light on this period of the past and provided a springboard for further research.

\section{Acknowledgements}

We are grateful to Bart Holterman for his comments on a draft of this paper.

\section{Endnotes}

1 Amongst the most recent contributions to the study of the Hanse trade at Bergen are the works by Burkhardt (2009), Nedkvitne (2014), and Wubs-Mrozewicz (2008).

2 Dollinger 2012.

3 On export goods of Iceland see Porsteinsson 1972, 191; Hofmeister 2001.

${ }^{4}$ DI 2, no. 343; for a summary of the discussion of this issue, see Porláksson 2010, 150.

5 See Boulhosa 2010, 179f for the problems in attempting to estimate more precisely the size of trade.

${ }^{6}$ Lorenzen-Schmidt below, Table 1; Holterman, in press.

7 Porláksson 2010, 150 suggests that the thirteenthcentury trade was about elite goods.

8 DI 4, no. 337; Hofmeister 2001, 34

9 Renfrew 1975; Mehler 2009, $91 \mathrm{f}$.

${ }^{10}$ Donaldson 1958.

${ }^{11}$ Oka and Kusimba 2008.

${ }^{12}$ DN 5, no. 23; Helle 2003, 415-417.

${ }^{13}$ For example, Hill 2004, $206 f$.

${ }^{14}$ Nedkvitne 2014, 62-66.

${ }^{15}$ For the collective action of the Bergen Kontor, see WubsMrozewicz 2012. 
16 Nedkvitne 2014, 335-339.

17 DN 8, no. 199.

${ }^{18}$ DN 19, no. 707

19 Gardiner 2016; Nedkvitne 2014, 518-529; Nedkvitne 2016, 53-56.

20 Childs 1995.

${ }^{21}$ Bergen is described in 1425 as the staple for merchant ships going to Hålogaland, Finnmark (in northern Norway) and Iceland: DI 4, no. 381.

22 The National Archives (TNA, Kew, London), SC8/102/5100.

23 Kowaleski 2003, 191-196.

24 See papers by Hammel-Kiesow and Hofmeister, below. The Dutch ship was, perhaps, bound for Bristol or France, because it is otherwise difficult to understand why it was choosing to sail through the Irish Sea, DN 20, no. 823 ; $D I 16$, no. 111.

${ }_{25}$ HUB 6, no. 582.

${ }_{26}$ DN 2, no. 797; Shetland Documents 1195-1579, no. 22; Crawford and Ballin Smith 1999, 39.

27 Rymer, Foedera 4, part 2, 150 b.

28 Statutes of the Realm 2, 239.

${ }^{29}$ DI 4, no. 578

30 Carus-Wilson 1954, 119n; Childs 1995, $18 \mathrm{f}$.

31 The Overseas Trade of Bristol, nos 84, 85, 103, 148, 156.

${ }^{32}$ DI 16, nos 85 (1427), 104 (1436), 107 (1437), 163 (1455).

33 DI 16, no. 210.

${ }^{34}$ DI 10, no. 23.

5 DI 16, no. 220.

36 Porsteinsson 1972, 175.

37 Calendar of Patent Rolls 1476-85, 23; DI 10, no. 26; Hofmeister 2000, 35; see Lorenzen-Schmidt below.

${ }^{38}$ DI 11, no. 22.

39 DI 16, no. 294 (pp. 553-554).

40 See Hammel-Kiesow below.

${ }^{41} D N$ 3, 931; DN 6, 589.

${ }^{42}$ DI 16, no. 230; DI 14, no. 318.

${ }^{43}$ DI 6, no. 617.

${ }^{44}$ Letters and Papers, Foreign and Domestic, of the Reign of Henry VIII, 1 (ii), 156; TNA, C76/191.

${ }_{45}$ DI 16, nos 250, 294 (page 554).

46 DI 16, no. 254.

47 Letters and Papers, Foreign and Domestic, of the Reign of Henry VIII, 1 (ii), 893.

${ }^{48}$ DI 16, no. 256.

49 DI 9, no. 243.

50 British Library, Cotton MS, Nero Biii, f. 108.

51 Porsteinsson 1957-61, 81f; Letters and Papers, Foreign and Domestic, of the Reign of Henry VIII, 5, 602.

52 TNA, HCA 13/92.

53 DI 11, no. 340

${ }^{54}$ Ibid., no. 367.

55 Ibid., no. 477.

56 Mehler 2015, $202 \mathrm{f}$.

57 Baasch 1889, 42.

58 For the actions of the Scots, see Calendar of the Manuscripts Preserved at Hatfield House 13, 70f; Calendar of State Papers Foreign, Elizabeth, 4, 177.

59 DI 14, nos 249, 250.

60 Holterman 2018, 102, who identifies the ports open to Hamburg merchants.

${ }^{61}$ See Lorenzen-Schmidt below; Porláksson 1999, 146-49.

62 Gunnarson 1983, 53f.
63 Jones 2000, 107.

64 Baasch 1889, 49f.

65 Ibid., 48; Aðils 1926; Gunnarson 1983, 53.

${ }^{66}$ Nedkvitne 2014, 319f.

67 Hastrup 1990, 54-57, $137 \mathrm{f}$.

68 Shetland Documents 1195-1579, no. 140. Friedland 1973.

69 Ibid., no. 237; see also Smith below.

70 Gardie Papers (private papers held at Gardie House, Bressay, Shetland), 357.

71 Zachariasen 1961, 161-184; Wylie 1987, 17.

72 DN 12, no. 452.

73 Wylie 1987, 25 f.

${ }^{74}$ For a recent discussion on the value of mercantilism as an analytical concept, see Stern and Wennerlind 2015.

75 On skattland, see Imsen 2010.

76 Spufford 1988, 339-362.

77 Porláksson, 2010, 157-161.

78 Nedkvitne 2014, 402, 406.

79 The Overseas Trade of Bristol, nos 83, 103.

${ }^{80}$ For example, SA, D6/97.

81 MacDonald 1935; see Smith below.

82 See also Hofmeister 2001.

83 SA, D12/110/9.

${ }^{84}$ Shetland Documents 1195-1579. no. 140 (p. 106).

${ }^{85}$ Nedkvitne 2014, 403.

86 Munro 1994, 151.

87 Pór 2009, 331.

88 Smith 1984, 61-65.

${ }^{89}$ DI 11, no. 340.

90 Mehler 2009.

91 Ehrenberg 1899, 24; Holterman 2018, 159-161. See also DI 16, 333.

92 DI 9, no. 262; Koch 1995, 195-198.

93 MacDonald 1935, 29.

94 Piebenga 1993.

95 Sigurdson 2016, 184-186.

96 Young 1979, 70f.

97 Smith 1989.

98 Daae 1882.

99 Ísleifsdóttir-Bickel 1996, 101, 178, 183.

${ }^{100}$ Porsteinsson 1972, 191.

101 Ísleifsdóttir-Bickel 1996.

102 Piper 1966.

${ }^{103}$ Porsteinsson 1972, 194.

${ }^{104}$ For the wider issue of colonialism in the North Atlantic, see Mehler and Gardiner 2013, 7-10.

${ }^{105}$ For Icelanders in Germany, see Koch 1995. For Icelanders in England, see Webb 1962, 87f and more generally, see England's Immigrants 1330-1550 Resident Aliens in the Late Middle Ages website: https:// www.englandsimmigrants.com and Lambert 2017.

${ }^{106}$ Seelmann 1883.

107 The First Boke of Introduction of Knowledge, 139, 141f.

108 TNA, PROB 11/8/318. We owe this reference to Anne Sutton.

${ }^{109}$ Mehler 2009, 98f.

110 Shetland Documents 1195-1579, no. 237, p. 211. By 1613 the charge for price-setting had risen to a toll of four barrels and many other items as well: SD 1612-1637, no. 55.

${ }^{111}$ See Hayeur Smith below.

112 Brand 1701, 67. 
${ }^{113}$ Skre 2014.

${ }^{114}$ Skre 2017.

${ }^{115}$ Ekroll et al. 2000, 136-139.

\section{References}

\section{Printed sources}

Calendar of the Manuscripts Preserved at Hatfield House, 13, 1917-1923. Historic Manuscripts Commission. London: HMSO.

Calendar of Patent Rolls 1476-85. London: HMSO.

Calendar of State Papers, Foreign Series, of the Reign of Elizabeth... Preserved in the Public Record Office. London: HMSO.

The First Boke of Introduction of Knowledge made by Andrew Borde (Early English Text Society, extra series, 10), 1870, ed. F. J. Furnivall. London: Early English Text Society.

Letters and Papers, Foreign and Domestic, of the Reign of Henry VIII. London: HMSO.

The Overseas Trade of Bristol, 1937, ed. E. Carus-Wilson. Bristol : Bristol Record Society.

Statutes of the Realm, 2, 1816, ed. A. Luders et al. London: Record Commissioners.

Rymer, T. 1739. Foedera, ed. G. Homes. London.

Seelmann, W. 1883. Gories Peerse's Gedicht Van Island. Jahrbuch des Vereins für niederdeutsche Sprachforschung 9, 110-145.

\section{Secondary literature}

Aðils, J. 1926. Den Danske Monopolhandel på Island, 1602-1787. Copenhagen: Gyldendalske Boghandel.

Baasch, E. 1889. Forschungen zur Hamburgischen Handelsgeschichte: 1. Die Islandfahrt der Deutschen: namentlich der Hamburger, vom 15 bis 17 Jahrhundert. Hamburg: Herold Buchhandlung.

Boulhosa, P. P. 2010. Of fish and ships in medieval Iceland, in S. Imsen (ed.), The Norwegian Domination and the Norse World c. 1100-c. 1400, 175-197. Trondheim: Tapir Academic Press.

Brand, J. 1701. A Brief Description of Orkney: Zetland, Pightland-Firth and Caithness. Edinburgh: George Mosman.

Burkhardt, M. 2009. Der hansische Bergenhandel im Spätmittelalter: Handel - Kaufleute - Netzwerke. Quellen und Darstellungen zur hansischen Geschichte 60. Köln: Böhlau.

Carus-Wilson, E. 1954. Medieval Merchant Venturers: Collected Studies. London: Methuen.

Childs, W. R. 1995. England's Iceland trade in the fifteenth century: the role of the port of Hull. Northern Seas Yearbook, 1995, 11-31. Esbjerg: Fiskeri- og Søfartsmuseet.

Crawford, B. E. and Ballin Smith, B. 1999. The Biggings, Papa Stour. Shetland. The History and Excavation of a Royal Norwegian Farm. Edinburgh: Society of Antiquaries of Scotland.

Daae, L. 1882. Didrik Pining. [Norsk] Historisk Tidsskrift 3(2), 233-245.

Dollinger, P. 2012 (newly edited by V. Henn and N. Jörn). Die Hanse (sixth revised edition; first published 1963). Stuttgart: Alfred Kröner Verlag.
Donaldson, G. 1958. Shetland Life under Earl Patrick. Edinburgh: Oliver and Boyd.

Ehrenberg, R. 1899. Aus der Hamburgischen Handelsgeschichte. Zeitschrift des Vereins für Hamburgische Geschichte 10, 1-40.

Ekroll, Ø., Stige, M., and Havran, J. 2000. Kirker i Norge: Middelalder i Stein. Oslo: Arfo.

Friedland, K. 1973. Der hansische Shetlandhandel, in K. Friedland, Stadt und Land in der Geschichte des Ostseeraums, 66-79. Lübeck: Schmidt-Römhild Verlag.

Gardiner, M. F. 2016. The character of commercial fishing in Icelandic waters in the fifteenth century, in J. H. Barrett and D. C. Orton (eds), Cod and Herring: The Archaeology and History of Medieval Sea Fishing, 8090. Oxford: Oxbow Books.

Gunnarson, G. 1983. Monopoly Trade and Economic Stagnation: Studies in the Foreign Trade of Iceland 1602-1787. Lund: Ekonomisk-Historiska Föreningen.

Hastrup, K. 1990. Nature and Policy in Iceland 1400-1800: An Anthropological Analysis of History and Mentality. Oxford: Clarendon Press.

Helle, K. 2003. Growing inter-Scandinavian entanglement, in K. Helle (ed.), The Cambridge History of Scandinavia: Volume I. Prehistory to 1520, 411-420. Cambridge: Cambridge University Press.

Hill, T. 2004. Die Stadt und ihr Markt. Bremens Umlandsund Außenbeziehungen im Mittelalter (12.-15. Jahrhundert). Stuttgart: Franz Steiner Verlag.

Hofmeister, A. E. 2000. Hansische Kaufleute im 15. und 16. Jahrhundert, in Kirche, Kaufmann, Kabeljau - 1000 Jahre Bremer Islandfahrt, 33-46. Bremen: Staatsarchiv.

Hofmeister, A. E. 2001. Das Schuldbuch eines Bremer Islandfahrers aus dem Jahr 1558. Bremisches Jahrbuch $80,20-50$.

Holterman, B. 2018. The Fish Lands: German Trade with Iceland, Shetland and the Faroes in the late 15th and 16th Centuries. Unpublished PhD thesis, University of Hamburg.

Holterman, B. in press. Size and composition of ship crews in German trade with the North Atlantic islands, in N. Mehler (ed.), German Voyages to the North Atlantic Islands (c. 1400-1700). Berlin: De Gruyter.

Imsen, S. 2010. Introduction, in S. Imsen (ed.), The Norwegian Domination and the Norse World c. 1100 c. 1400. Tapir Academic Press: Trondheim.

Ísleifsdóttir-Bickel, V. A. 1996. Die Einführung der Reformation in Island 1537-1565. Die Revolution von oben. Frankfurt am Main: Peter Lang.

Jones, E. 2000. England's Icelandic fishery in the Early Modern period, in D. J. Starkey, C. Reid and N. Ashcroft (eds), England's Sea Fisheries: The Commercial Sea Fisheries of England and Wales since 1300, 105-110. London: Chatham Publishing.

Koch, F. C. 1995. Isländer in Hamburg 1520-1662. Untersuchungen über den Aufenthalt von Isländern in Hamburg für den Zeitraum 1520-1662 (Beiträge zur Geschichte Hamburgs 49). Hamburg: Geschichtsverein.

Kowaleski, M. 2003. The commercialization of the sea fisheries in medieval England and Wales. International Journal of Maritime History 15(2), 177-231.

Lambert, B. 2017. Scandinavian immigrants in late medieval England: sources, problems and patterns, in S. S. Hamre (ed.), Foreigners and Outside Influences in Medieval Norway, 111-123. Oxford: Archaeopress. 
MacDonald, G. 1935. More Shetland tombstones, Proceedings of the Society of Antiquaries of Scotland 69, 27-48.

Mehler, N. 2009. The perception and interpretation of Hanseatic material culture in the North Atlantic: problems and suggestions. Journal of the North Atlantic special volume $1,89-108$.

Mehler, N. 2015. The sulphur trade of Iceland from the Viking Ages to the end of the Hanseatic period, in I. Baug, J. Larsen and S. Samset Mygland (eds), Nordic Middle Ages - Artefacts, Landscapes and Society. Essays in Honour of Ingvild Øye on her Seventieth Birthday, 193-212. Bergen: University of Bergen.

Mehler, N. and Gardiner, M. F. 2013. On the Verge of Colonialism: English and Hanseatic Trade in the North Atlantic Islands, in P. Pope and S. Lewis-Simpson (eds), Exploring Atlantic Transitions: Archaeologies of Permanence and Transience in New Found Lands, 1-15. Woodbridge: Boydell \& Brewer.

Munro, J. H. 1994. Patterns of trade, money, and credit, in T. A. Brady, H. O. Oberman, and J. D. Tracy (eds), Handbook of European History, 1400-1600: Late Middle Ages, Renaissance and Reformation, Vol. I: Structures and Assertions, 147-195. Leiden: Brill.

Nedkvitne, A. 2014. The German Hansa and Bergen 11001600. Cologne: Böhlau Verlag.

Nedkvitne, A. 2016. The development of the Norwegian long-distance stockfish trade, in J. H. Barrett and D. C. Orton (eds), Cod and Herring: The Archaeology and History of Medieval Sea Fishing, 50-59. Oxford: Oxbow Books.

Oka, R. and Kusimba, C. 2008. The archaeology of trading systems, part 1: towards a new trade synthesis. Journal of Archaeological Research 16, 339-395.

Piebenga, G. A. 1993. Gozewijn Comhaer - Carthusian and modern devout, in F. Akkerman, G. C. Huisman and A. J. Vanderjagt (eds), Wessel Gansford (1419-1489) and Northern Humanism (Brill's Studies in Intellectual History 40), 180-192. Leiden: Brill.

Piper, K. 1966. Die Kirche der hamburgischen Islandfahrer in Hafnarfjördur. Hamburger Geschichts- und Heimatblätter 62, 227-232.

Renfrew, C. 1975. Trade as action at a distance: questions of integration and communication, in J. A. Sabloff and C. C. Lamberg-Karlovsky (eds), Ancient Civilization and Trade, 3-59. Albuquerque: University of New Mexico Press.

Sigurdson, E. 2016. The Church in Fourteenth-Century Iceland: The Formation of an Elite Clerical Identity. Leiden: Brill.

Skre, D. 2014. Norðvegr - Norway: from sailing route to kingdom. European Review 22, 34-44.
Skre, D. 2017. Avaldsnes - A Sea-Kings' Manor in FirstMillennium Western Scandinavia. Berlin: De Gruyter.

Smith, B. 1989. In the tracks of bishop Andrew Pictoris of Orkney, and Henry Phankouth, archdeacon of Shetland. The Innes Review 40(2), 91-105.

Smith, H. D. 1984. Shetland Life and Trade 1550-1914. Edinburgh: John Donald.

Spufford, P. 1988. Money and its Use in Medieval Europe. Cambridge: Cambridge University Press.

Stern, P. J. and Wennerlind, C. 2015. Introduction, in P. J. Stern, and C. Wennerlind, (eds), Mercantilism Reimagined: Political Economy in Early Modern Britain and its Empire, 3-22. Oxford: Oxford University Press.

Pór, J. P. 2009. Icelandic fisheries, c. 900-1900, in D. J. Starkey, J. P. Pór and I. Heinbrink (eds), A History of the North Atlantic Fisheries. Volume 1: From Early Times to the Mid-Nineteenth Century, 323-349. Bremen: H. M. Hauschild.

porláksson, H. 1999. Sjórán og siglingar: ensk-Íslensk samskipti 1580-1630. Reykjavík: Mál og Menning.

Porláksson, H. 2010. King and commerce: the foreign trade of Iceland in medieval times and the impact of royal authority, in S. Imsen (ed.), The Norwegian Domination and the Norse World c. 1100 - c. 1400, 149-174. Trondheim: Tapir Academic Press.

porsteinsson, B. 1957-61. Henry VIII and Iceland. SagaBook of the Viking Society 15, 67-101.

Porsteinsson, B. 1972. Island, in G. A. Blom, A. E. Christensen, E. Lönnroth, V. Niitemaa, and B. Porsteinsson (eds), Hansestæederne og Norden (Det Nordiske Historikermøde i Århus, 7-9 August 1957), 165-195. Aarhus: Universitetsforlaget i Aarhus.

Webb, J. 1962. Great Tooley of Ipswich: Portrait of an Early Tudor Merchant. Ipswich: Suffolk Record Society.

Wubs-Mrozewicz, J. 2008. Traders, Ties and Tensions: The Interactions of Lübeckers, Overijsslers and Hollanders in Late Medieval Bergen. Hilversum: Verloren Publishers.

Wubs-Mrozewicz, J. 2012. The medieval Hanse: groups and networks of traders. The case of the Bergen Kontor (Norway), in J. Á. Solórzano Telechea, M. Bochaca and A. Aguiar Andrade (eds), Gentes de Mar en la Ciudad Atlántica Medieval, 213-233. Logroño: Instituto de Estudios Riojanos.

Wylie, J. 1987. The Faroe Islands. Interpretations of History. Lexington: University Press of Kentucky.

Young, G. V. C. 1979. From the Vikings to the Reformation: A Chronicle of the Faroe Islands up to 1538. Isle of Man: Shearwater Press.

Zachariasen, L. 1961. Føroyar sum rettarsamfelag 15351655. Tórshavn: Føroya Fróðskaparfelag. 